\title{
Zero Waste Accounting for Islamic Financial Institutions in Indonesia and Its Role in Achieving Sustainable Development Goals
}

\author{
Yaser Taufik Syamlan', Murniati Mukhlisin ${ }^{2 *}$ \\ *Corresponding author
}

\begin{abstract}
This study aims to propose a model of Zero Waste Accounting in Islamic Financial Institutions in Indonesia and how it is relevant to the achievement of Sustainable Development Goals (SDGs). Due to the nature of the research which is exploration thus the research adopts interpretative approach which is essential to validate the research with "convincingness" approach rather than positivist measures of the reliability, validity of data and the generalization of results. The finding documents that Zero Waste Accounting is in vein with the spirit of Maqashid ul-Shariah that has been embedded as a part of the purpose of Islamic financial institution establishment. Statement of Sources and Uses of Zero Waste Accounting should become one of the additional disclosures. The paper sheds a light the need on Zero Waste Accounting for the accounting standard setters.
\end{abstract}

Keywords: zero waste accounting, Islamic financial institutions, SDGs

JEL Classification: G20, G52,Q56

\begin{abstract}
Abstrak. Penelitian ini bertujuan untuk mengusulkan model zero waste accounting di lembaga keuangan syariah di Indonesia dan bagaimana relevansinya dengan pencapaian pembangunan ekonomi berkelanjutan (SDGs). Penelitian ini bersifat eksplorasi maka penelitian mengadopsi pendekatan interpretatifyang penting untuk memvalidasi penelitian dengan pendekatan "meyakinkan" daripada ukuran positivis dari keandalan, validitas data dan generalisasi hasil. Temuan penelitian ini mendokumentasikan bahwa zero waste accounting sejalan dengan semangat Maqashid ul-Shariah yang telah tertanam sebagai bagian dari tujuan pendirian lembaga keuangan Islam. Pernyataan Sumber dan Penggunaan zero waste accounting harus menjadi salah satu pengungkapan tambahan. Makalah ini menyoroti kebutuhan zero waste accounting untuk penentu standar akuntansi.
\end{abstract}

Kata Kunci: zero waste accounting, lembaga keuangan syariah, SDGs

\section{How to Cite:}

Syamlan, Y. T., \& Mukhlisin, M. (2020). Zero Waste Accounting for Islamic Financial Institutions in Indonesia and Its Role in Achieving Sustainable Development Goals. Etikonomi: Jurnal Ekonomi, 19(2), 365 - 382. https://doi.org/10.15408/ etk.v19i2.15538. 


\section{Introduction}

Islamic Finance Development in Indonesia has been growing rapidly especially during 2016-2017 as presented in the Table 1. However, it would be reversed in 2020 as Ministry of Finance predicted the impact of Covid-19 would diminish Indonesian economic growth to $2.3 \%$ or even $-0.4 \%$. Since the economic activities are diminishing, Islamic banking would face tight collection or high Non-Performing Financing (NPF) by the end of the year.

Table 1. Assets of Islamic Finance in Indonesia (IDR Billion)

\begin{tabular}{lrrrrr}
\hline \multicolumn{1}{c}{ Industry } & $\mathbf{2 0 1 5}$ & $\mathbf{2 0 1 6}$ & $\mathbf{2 0 1 7}$ & $\mathbf{2 0 1 8}$ & $\mathbf{2 0 1 9}$ \\
\hline Islamic Banking & 296,262 & 356,504 & 424,181 & 477,327 & 524.564 \\
Islamic Insurance & 26,519 & 33,244 & 40,606 & 41,959 & 45,453 \\
Islamic Stock market capitalization & $2,600,851$ & $3,170,056$ & $3,704,543$ & $3,666,688$ & $3,744,816$ \\
Outstanding Tradable Sovereign Sukuk & 255,794 & 372,096 & 512,339 & 605,809 & $3,805,478$ \\
$\begin{array}{l}\text { Outstanding Non-Tradable Sovereign } \\
\text { Sukuk }\end{array}$ & 41,781 & 39,282 & 39,221 & 40,643 & 209,325 \\
\hline
\end{tabular}

Source: various sources

As for Islamic insurance, it showed more positive growth from 2018 to 2019 however, again, Covid-19 would hit the opportunity of its travelling insurance significantly as 300,000 $-500,000$ umrah travellers were not allowed to perform umrah to Saudi Arabia since end of February due to the fear on contagion of Covid-19 (Republika, 2020). Islamic stock market capitalization would suffer even further as the trading has not been so favorable, high capital outflow and low market confidence. From government side, Sukuk would be then a heavy burden to pay back the rental fee to the investors. The commercial purpose of IFIs should be combined with its social purpose or known as the integration between Islamic Commercial Finance and Islamic Social Finance.

Commercial purpose is important part in IFIs to ensure its going concern principle and social finance is essential to balance the commercial motive with sharing in the economy. These both would then address completely to the urgency of SDGs. For instance, how can we achieve "Reduce in Equalities" the 10th SDG objective if there is no commercial purpose to empower people in economy, and how can we target "Clean Water and Sanitation" the 6th SDG objective if there is no social finance involved such as the execution of zakat, infaq, shadaqah, waqf.

Environmental issues appeared as trending issues that have been promoted from almost every sector institution to achieve SDGs for instance in every World Economic Forum. The report places the economy and environment as the world's main risks. Both have a connection where it is believed that environmental destruction is caused unsustainable industrial governance has eventually a negative impact to the global economy. This is what drives the strengthening efforts reconstruction of development policies where there is a balance between efforts encourage economic growth, social equity and environmental preservation life. However, when compared to many other economic sectors, IFIs do not bear the same consumption of energy, water, and paper usage. Nevertheless, all IFIs play an intermediary 
role in the economy that are very relevant to the environment because they can provide funding that is related to energy (See Figure 1).

Due to the vital role of environment in the eye of Islam, thus IFIs should develop more sustainable products, such as environmental, social, or ethical investment funds. Specifically, the label would be: "Zero Waste Islamic Financial Institutions", to replace "Green Banking" that has been popular earlier. As such, encouraging environmentally responsible products and services as well as activities should be one of the responsibilities of IFIs. Furthermore, all IFIs should become zero waste oriented in their activities that will be mutually beneficial for banks, industry and the economy. Biswas (2011) argues that the concept of green banking (similar effort to zero waste) will ensure the greening of the industry but also will improve the quality of bank assets in the future.

Figure 1. Islamic Finance Perspective (Commercial Finance and Social Finance)

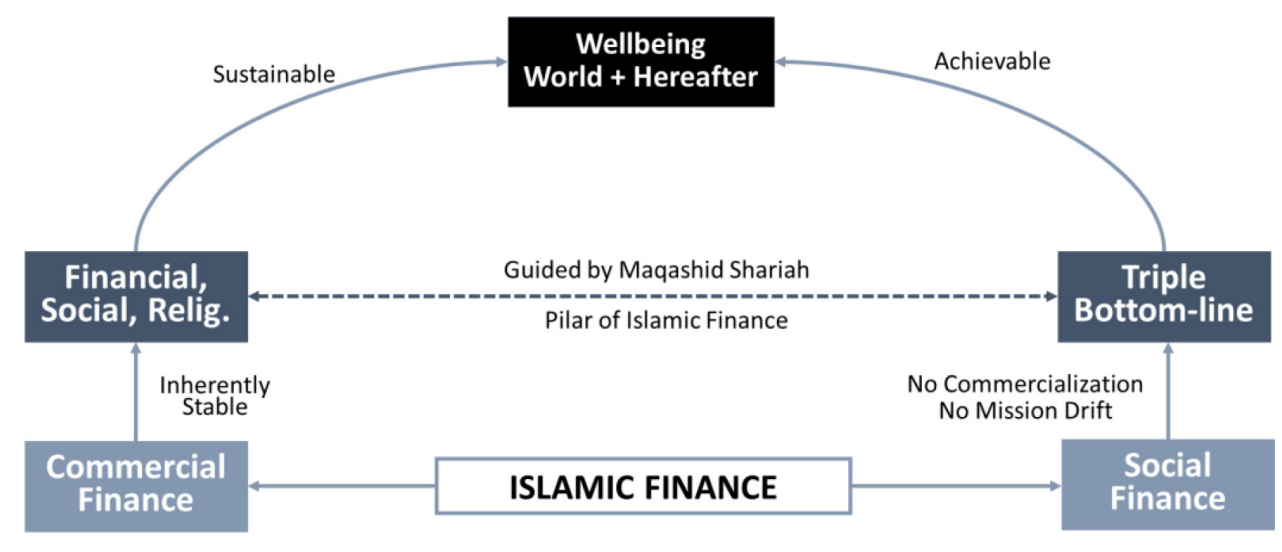

Source: Ascarya (2017)

The concept of green banking is defined as promoting environmentally friendly practices and reducing carbon footprint that involves a two-pronged approach (Islam and Das, 2013). First, green banking focuses on the green transformation of all banks' internal operations. This means that all banks must adopt appropriate ways to utilize renewable energy, automation and other measures to minimize the carbon footprint of banking activities. Second, all banks must adopt environmentally responsible financing; consider project environmental risks, before making financing decisions; and in particular supporting and encouraging the growth of future 'green' initiatives projects.

Some countries have applied such concept of green banking, for example Bangladesh, India, and South Korea. There are 45 banks in Bangladest that have formulated policy for green banking, 46 banks have formed a Green Banking unit, and 41 Banks have introduced a Green Office Guide. However, the research conducted by Islam \& Das (2013) conclude that Bangladesh is one of the most climate change vulnerable countries to climate change in the world. From the overall discussion, it can be said that green banking practices in Bangladesh are not at a satisfactory level. It is supported by research by Hossain et al (2016) where Islamic banks in Bangladesh made some green banking categories but not all banks present their full reports as shown on the following Table 2. 
Table 2. Number of Islamic Banks in Bangladesh Reporting Green Banking Issues

\begin{tabular}{clccc}
\hline No & \multicolumn{1}{c}{ Items } & $\mathbf{2 0 1 1}$ & $\mathbf{2 0 1 2}$ & $\mathbf{2 0 1 3}$ \\
\hline 1 & Energy efficiency/savings & 6 & 7 & 9 \\
2 & Electricity consumption/saving & 5 & 7 & 8 \\
3 & Gas/fuel consumption & 4 & 5 & 7 \\
4 & Water consumption/saving & 5 & 7 & 8 \\
5 & Paper consumption/saving & 5 & 6 & 8 \\
6 & Green finance & 4 & 7 & 8 \\
7 & General statement on climate change and global warming & 7 & 6 & 9 \\
8 & Mentioning of carbon emission or footprint & 2 & 3 & 5 \\
9 & Climate change responsibility & 5 & 5 & 7 \\
10 & Climate change funds & 5 & 7 & 6 \\
11 & Establishment of green banking unit & 4 & 7 & 8 \\
12 & Establishment of green banking policy & 5 & 8 & 8 \\
13 & Green banking products & 5 & 5 & 5 \\
14 & Online/mobile/SMS banking & 5 & 8 & 9 \\
15 & Social awareness creation & 5 & 7 & 8 \\
16 & Sector specific green banking policy & 5 & 4 & 5 \\
\hline
\end{tabular}

Source: Hossain et al. (2016)

In Indonesia itself, the monetary authority -Bank of Indonesia- has conducted some regulations supporting this issues, thus the banking sector must have sustainability report as proving that the banks including Islamic banks also contribute to achieve SDGs. For example Bank of Sharia Mandiri (BSM) where it is committed to distributing economic values for stakeholders through employee welfare, government taxes, zakat and community welfare funds. In its 2018 Sustainability Reporting, BSM has managed to achieve Mudharib fund management revenues of Rp7.69 trillion, an increase of 5.2\% compared to the previous year of Rp7.29 trillion (BSM, 2019). BSM also supports sustainability with their product portfolio which is to be disclosed to support the bank's commitment in innovating service products that support sustainable finance and maintaining low Non Performing Finance (NPF) performance. The development of a sustainable financial product portfolio has an impact on sustainable business growth as well as contributes to the success of national development through financing in strategic economic sectors.

In committing finance sustainability practices by considering environmental aspects, BSM prioritizes financing for prospective customers or debtors who are evaluated to carry out environmental preservation. On the other hand, the bank avoids financing any business that does not meet environmental requirements (Environmental Impact Assessment). BSM did not have a voting policy regarding environmental or social issues, thus, to ensure that prospective customers with their business prospects meet the green finance criteria, BSM evaluates technical/production aspects through analysis of environmental impacts that 
questions: first, pollution in the production process; second, efforts to mitigate pollution; third, complaints from residents in the local area; 4) Practicing government regulations.

For prospective customers in the palm oil industry, BSM has set specific requirements that have to be met, including being certified with Indonesian Sustainable Palm Oil (ISPO) or Roundtable Sustainable Palm Oil (RSPO). For registered customers of the oil palm industry who had previously being funded yet had not being certified with ISPO or RSPO, the Bank has appealed to the the customers to immediately proceed the ISPO or RSPO certificate. It means, for corporate segment is required to meet the Company Environmental Performance Rating (PROPER Rating) at least at 'Blue' or 'Green' rating. The achievement of 'Blue' PROPER reflects the company's compliance with environmental regulations. Based on the screening process related to the compliance of the corporate segments toward Green Finance criteria, financing products that may be categorized in the "green portfolio" included renewable energy power projects. However, it is clear that Bangladeshi and Indonesian Islamic financial institutions (in this case Islamic banks) limit their report to green banking instead of Zero Waste Accounting. The awareness on Zero Waste Accounting and SDGs highlight are not specifically mentioned.

This paper will address three research questions; How are the Relations of SDGs, Islamic Finance and Zero Waste Accounting?; How Relevant the Zero Waste Accounting for Islamic Financial Institution?; How is the proposal of Zero Waste Accounting for Islamic Financial Institution?. This paper has main objective to propose the zero waste accounting for the Islamic financial institution. This paper consists of several sections. Section Two explains the methodology, Section Three explain deeply the effort to answer research question. Lastly, the paper suggests the conclusion and implications of Section Five.

\section{Method}

This paper adopts interpretative approach which is essential to validate the research with "convincingness" approach rather than positivist measures of the reliability, validity of data and the generalization of results. The originality and critical interpretation combined with the "convincingness" approach is expected to describe the procedural validity of accounting research as previously proposed by Alsharari \& Al-Shboul (2019). As this paper has a proposal to accounting standard setters for disclosing Zero Waste Accounting in IFIs, in which is it is a part of hifdzul 'alam (protecting the environment) therefore it is appropriate if this paper adopts Maqāsid al-Shariah framework in its discussion.

According to Abdurrachman (2008) mechanism to issue a ruling can be through several ways such as lil hajäh (based on needs), lil mashlahah (based on welfare of society), and lil maqāsid al-shariah (based on objectives of Sharia). Whichever way is chosen, the scholars must refer to the main sources of law i.e. Qur'an and Sunnah. The commonalities have existed among IFIs that they must operate under Islamic ethical business framework drawn by Sharia underpinning (Haniffa \& Hudaib, 2007). Thus, they should disclose information in accordance with sharia standards and sharia values on their financial reporting standards. To ensure the standards are in line with sharia, its main references should be Qur'an and 
authentic sunnah with additions of ijtihäd (derived rule), ijma' (consensus), and qiyas (deductive analogy). These legal frameworks should be included when measuring sharia obedience of IFIs such as in reporting their activities.

The objectives of Shariah are principally known as Maquasid ul-Shariāh pronounced by Al-Ghazali (1058-1111). The discussion on Maqāsid ul-Shariäh was started when scholars like Al-Ghazali, Ibn al-Hajib and al-Shatibi defined primary needs (dharüriyyah) as the preservation and safeguarding of five principles such as protection of religion (din), protection of life (nafs), protection of intellect ('aql), protection of wealth ( $m \bar{a} l)$, and protection of lineage (ansab) (Chapra, 2008; Abdullah \& Furqani, 2012). These basic principles are important in every human life or institutions to ensure long term sustainability and prosperity of the economic development and welfare of the people. As belief in the hereafter under Islamic teaching is essential, therefore fulfilling human basic needs that covers the protection of these five principles is also for the purpose of preparing the day of judgment that would be held in the hereafter. This is as noted by Al-Ghazali: "preventing the loss of these five fundamentals (usul) and protecting them can never be neglected in any religious community (millah) or legal system (Sharia) that is meant for the good and well-being (shaläh) of human beings'. This concept would be a consideration of a mashlahah that we know by necessity was intended by the Shariah, not on the basis of one single proof or one particular rule, but on multiple proofs that are beyond enumeration. There is a red line when discussing the role of IFIs with SDGs, Zero Waste Accounting and Maqāsid al-Shari'ah and it has become paramount how accounting could serve as accountability platform to the stakeholders.

\section{Result and Discussion}

On 15 September 2015, Millenium Development Goals (MDGs) were replaced by Sustainable Development Goals (SDGs) as a new set of development target adopted by the member countries of United Nation. It contains 17 aspects focusing on five keys elements: People, planet, peace, prosperity, and partnership. 17 aspects SDGs are: (1) No Poverty; (2) Zero Hunger; (3) Good Health and Well-Being; (4) Quality Education; (5). Gender Equality; (6). Clean Water and Sanitation; (7) Affordable and Clean Energy; (8) Productive Employment and Economic Growth; (9) Industry, Innovation, and Infrastructure; (10) Reduced Inequalities; (11) Sustainable Cities and Communities; (12) Responsible Consumption and Production; (13) Climate Action; (14) Life Below Water; (15) Life on Land; (16) Peace, Justice and Strong Institution; (17) Partnership for Global Development. It is guidance for global action over the next 15 years (WDI, 2016).

Given this approach, every country must overcome poverty and hunger and ensure that everyone can have a healthy environment. In addition to ensuring everyone is free from fear and violence through strong global cooperation. This agenda will end in 2030. In Islam, SDGs as a whole have been thoroughly discussed. First, No Poverty; Have you seen the one who denies the Recompense? "(1) For that is the one who drives away the orphan (2) And does not encourage the feeding of the poor (3)" (QS Al-Maun: 1-3). Second, Zero Hunger; "And We will surely test you with something of fear and hunger and a loss of wealth and 
ives and fruits, but give good tidings to the patient "(QS Al-Baqarah: 155). Third, Good Health and Well-Being; The Prophet said, "There are two blessings which many people lose: (They are) Health and free time for doing well” (HR. Bukhari No. 6412). Fourth, Quality Education; "...Allah will raise those who have believed among you and those who were given knowledge, by degrees. And Allah is acquainted with what you do" (QS Al-Mujadilah: 11). Fifth, Gender Equality; "O mankind, indeed We have created you from male and female and made you peoples and tribes that you may know one another. Indeed, the most noble of you in the sight of Allah is the most righteous of you. Indeed, Allah is Knowing and Acquainted" (QS. Al-Hujurat: 13). However, this point may differ between UN definitions on Gender Equality with that of Islam's definition, as equality does not mean everyone has the same share (this debate is not discussed as it is beyond the scope of this paper).

Sixth, Clean Water and Sanitation; “... and made from water every living thing? Then will they not believe?" (QS. Al-Anbiya: 30). Seventh, Affordable and Clean Energy; "And have you seen the water that you drink?" (QS. Al-Waqi'ah: 68). Eight, Productive Employment and Economic Growth; The Prophet said, "Nobody has ever eaten a better meal than that which one has earned by working with one's own hands. The Prophet of Allah, David used to eat from the earnings of his manual labor" (HR Bukhari No. 2072). Ninth, Industry, Innovation, and Infrastructure; "Indeed, in the creation of the heavens and the earth and the alternation of the night and the day are signs for those of understanding" (QS. Ali 'Imran: 190). Tenth, Reduced Inequalities; “... so that it will not be a perpetual distribution among the rich from among you...." (QS. Al-Hashr: 7). Eleventh, Sustainable Cities and Communities; “... Indeed, Allah will not change the condition of a people until they change what is in themselves...." (QS. Ar-Ra'd: 11). Twelveth, Responsible Consumption and Production; "O children of Adam, take your adornment at every masjid, and eat and drink, but be not excessive. Indeed, He likes not those who commit excess" (QS. Al-A'raf: 31). Thirteenth, Climate Action; "But if the Truth had followed their inclinations, the heavens and the earth and whoever is in them would have been ruined. Rather, We have brought them their message, but they, from their message, are turning away" (QS. Al-Mu'minun: 71).

Fourteenth Life Below Water; "And it is He who subjected the sea for you to eat from it tender meat and to extract from it ornaments which you wear. And you see the ships plowing through it, and [He subjected it] that you may seek of His bounty; and perhaps you will be grateful” (QS. An-Nahl: 14). Fifthteenth, Life on Land; "It is He who enables you to travel on land and sea until, when you are in ships and they sail with them by a good wind and they rejoice therein, there comes a storm wind and the waves come upon them from everywhere and they assume that they are surrounded, supplicating Allah, sincere to Him in religion, "If You should save us from this, we will surely be among the thankful" (QS. Yunus: 22). Sixteenth Peace, Justice and Strong Institution; "O you who have believed, be persistently standing firm for Allah, witnesses in justice, and do not let the hatred of a people prevent you from being just. Be just; that is nearer to righteousness. And fear Allah; indeed, Allah is Acquainted with what you do" (QS. Al Maidah: 8). Seventeenth Partnership for Global Development; “... And cooperate in righteousness and piety, but do not cooperate in sin and aggression. And fear Allah; indeed, Allah is severe in penalty” (QS. Al Maidah: 2). 
There are several goals that are directly related to the Islamic finance field such as Poverty, Hunger, Health, Quality education, and Gender equality, Infrastructure, Consumption and Production. First, Islamic finance as tools for alleviate poverty and hunger. Poverty and hunger serve as two vital points in SDGs which have been the main global issues for long time a go. Many research papers present the best solution to solve it, but the problem still remains. One of the most considerable poverty eradication programme is through Islamic social finance instruments such as zakat, infaq, shadaqah, and waqf as tool of wealth equality among the rich and the poor and make sure the needy can afford the food for their daily life. Further, Islamic commercial finance introduces Islamic microfinance where it provides financing program for the low income society so that they can develop themselves to be better financially. Second, Islamic finance to empowering women. Women involvement in Islamic microfinance has been remarkably seen as potential players to the success of the poverty alleviation program in countries where group based programs operate. Group based programs in the microfinance area have been widely spread such as Grameen Model in Bangladesh that has recruited 7.06 million borrowers where 97 per cent of them are women (Yunus, 2007).

Empowering women in the economy creates social capital, which eventually contributes to the achievement of shared prosperity in the society and increased social cohesion that are critical for economic development and sustainability. Third, Islamic finance for infrastructure has been predominant in Islamic developing countries such as Indonesia, Malaysia, Saudi Arabia and others. In Islamic finance, some instruments and contracts are available in conducting public infrastructure financing that implement sharia-compliant principles as well, such as Istishna contract and sukuk for infrastructure financing. Fourth, Islamic compliance no only able to be applied in money market such as Islamic banking and finance but also in the real market. Muslims are bound by Islamic ethics and morals in the market place where consumers and producers must not consume or produce unlawful products or activities. Consumers and producers must spend part of their wealth to the less fortunate members in Islamic society and consumers are required to show moderation in their consumption. Yahya bin Umar (213-289 H) with his book 'Ahkam As Suq' argues that tasir (price determination), ihtikar (monopoly rent seeking), dan siyasah al ighraq (dumping) are not allowed in Islamic economic practices (Subhan, 2015).

Given the above background, it is very essential that there is a need to compose special accounting presentation to highlight the attention on Zero Waste Accounting by Islamic financial institutions (IFIs). It is due to the motivation that comes from Maqashid ul-Shariah, which is to promote protection of the environment (hifdzul bi'ah or hifdzul 'alam) (Mukhlisin et al., 2020). However, there is no so far a specific accounting on this issue. Thus, a research question for this paper is to what extent do Islamic financial institutions need to disclose Zero Waste Accounting in order to support SDGs? The purpose of this paper is therefore to propose a model of Zero Waste Accounting in Islamic Financial Institutions in Indonesia and how it is relevant to the achievement of SDGs.

Several SDGs stated above are also related to Zero Waste issues such as "Good Health and Well-Being", "Affordable and Clean Energy", "Sustainable Cities and Communities," 
"Climate Action", "Life Below Water and Life on Land." To achieve these SDGs, it is necessary to access financial services for the whole community or financial inclusion (Klapper et al., 2016). Discussing Zero Waste Accounting should be relevant to a term of "circular economy", a restoration industry system, where the economy of utilizing the waste products from the business that has been run (see Figure 2). Basically circular economy is a change in the environment in the face of global needs for economic ecology, and requires human economic activities that are consistent with the three basic principles of reducing, reusing and recycling to actually minimize the waste until the zero waste achieved (Lahti et al, 2018).

\section{Figure 2. The Concept of Circular Economy}

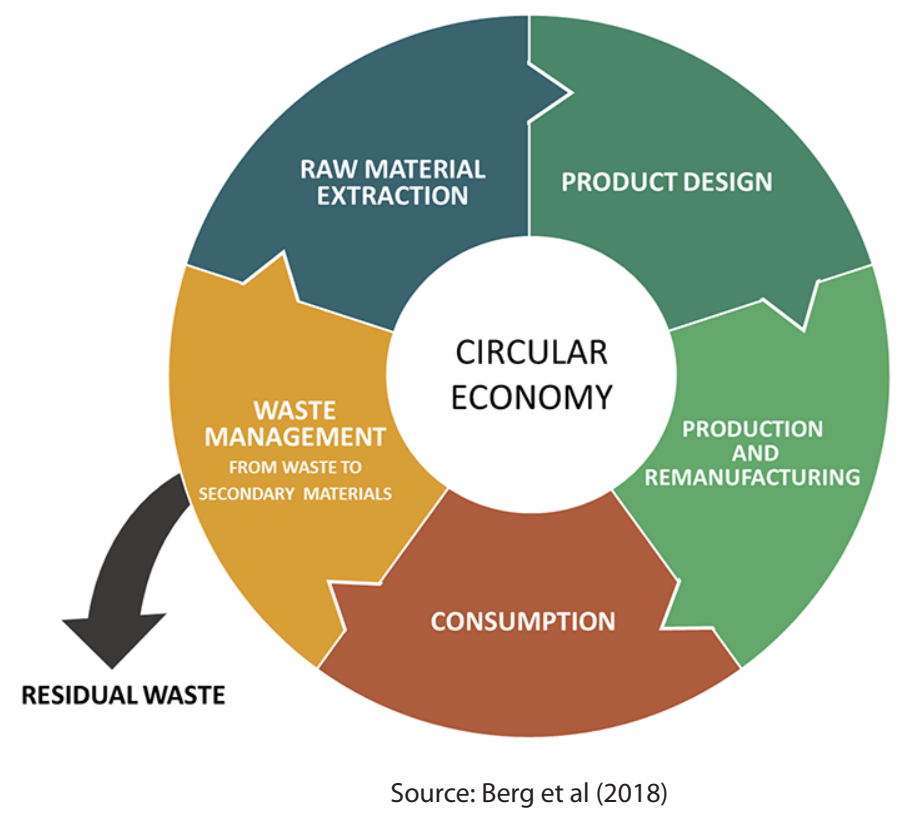

Like the basic principle of a circular economy, the system basically aims to attain the zero waste by designing waste into a new product that can be re-optimized for its benefits. The presence of the circular economy concept is a paradigm for economic development to go beyond the zero waste. Besides that it is also a response to the conventional economic model that is not sustainable using an economic linear system that is "take-make dispose", therefore circular economy replaces the concept with a business model such as "end-of-life ", which can achieve the economic goals of sustainable development and beckon the creation of environmental quality, social equality, and economic prosperity for present and future generations (Berg et al, 2018). Following is the pattern of circular economy with the concept of "end-of-life".

The circular economy concept is not new because academics and previous economic practitioners have discussed it. In the 1970s economists discussed the circular theory of the economy and the result was that this system had a high potential for developing the world economy. Until 2014, Europe became a pioneer in applying the circular economy concept that was implemented in the "Zero Waste for Europe" program, following the development of economic activity in Europe, many European countries had applied the circular economy 
concept strategy in their business sectors, such as Finland, Netherlands, Scotland, and France. In 2016 Finland became the first country in the world to issue a circular economy road map facilitated by Sitra Studies in collaboration with business sector ministries and stakeholders. Currently throughout the world the circular economy concept has been widely used by governments, entrepreneurs, and academics, although it has not been used consistently. It serves as a toolbox consists of implementation approaches for achieving SDGs (Schroeder et al., 2018).

Agustia et al (2018) argue that companies that create Green Innovation will gain both in terms of economic benefits and competitive advantage, which eventually will increase the value of the firm. It appears to see that there are risks in green accounting's promotion and mobilization that may tarnish the positioning of green accounting practice (Gallhofer \& Haslam, 1997). This could be because the green accounting only focuses on forestation and carbon emission. In Zero Waste Accounting, the focus will be more on to the generation of waste into something useful for human life. In other area such as in conservation activity to protect the nature, Barker (2019) proposes that conservation accounting serve informational needs of shareholders and environmentally sustainable business models. From governance perspective, Owen et al (1997) confirms that the ownership concentration ratio influences the quality of the circular economy accounting information disclosure. It means, from the governance side, the ownership can influence disclosure quality of the circular economy. On risk governance, $\mathrm{Ng}$ (2018) argues that three listed companies show their heterogeneous approaches to embracing risk governance, sustainable accounting and financing in their issuance of green bonds. Further, she proposes a theoretical framework that reinforces effects of legitimate policy and market-based finance to produce green financing system.

There are many previous studies about zero waste economy but the previous studies about Zero Waste Accounting in achieving SDGs and developing Islamic finance still quite limited. The strongest relationships exist between zero waste practices and the targets of SDG 6 (Clean Water and Sanitation), SDG 7 (Affordable and Clean Energy), SDG 8 (Decent Work and Economic Growth), SDG 12 (Responsible Consumption and Production), and SDG 15 (Life on Land) and CE practices can be applied as a "toolbox" and specific implementation approaches for achieving a sizeable number of SDG targets. This study in line with Muller (2018) that Circular Economy can help in achieving SDG targets and Circular economy should be regarded as a means, not an end of SDG 2 (Zero Hunger), SDG 6 (Clean Water and Sanitation), SDG 7 (Affordable and Clean Energy), SDG 9 (Industry, Innovation, and Infrastructure) SDG 11 (Sustainable Cities and Community), SDG 12 (Responsible Consumption and Production), SDG 13 (Climate Action), SDG 14 (Life Below Water), and SDG 15 (Life on Land).

To date, Pernyataan Standar Akuntansi Keuangan Syariah/Shariah Financial Reporting Standards (PSAK) Sharia adopted by IFIs only highlights social reporting in form of zakat, infaq, waqf and other social fund. PSAK 101 shows format on how to report the activities, such as Statement of Sources and Uses of Zakat, Sources and Uses of Qardhul Hasan. As for waqaf report, it is a merely collection that is disbursed to Waqf Nadzir, usually institutions that manage productivity of the waqf assets. Nevertheless, PSAK 109 
is separate standard for Zakat Institutions and PSAK 112 is standard for waqf reporting prepared by the Nadzir.

Although IFIs have not prepared any specific report regarding Zero Waste Accounting besides the sustainability reporting described above, there are several benchmarks from the conventional counter parts. Andreeva et al. (2018) argue that financial institutions could support green economy development by following responsible funding or targeted economic projects' investing principles through Green investment: Bonds, Insurance, Mortgage, Funds, and Taxes.

Figure 3. Green Project Framework

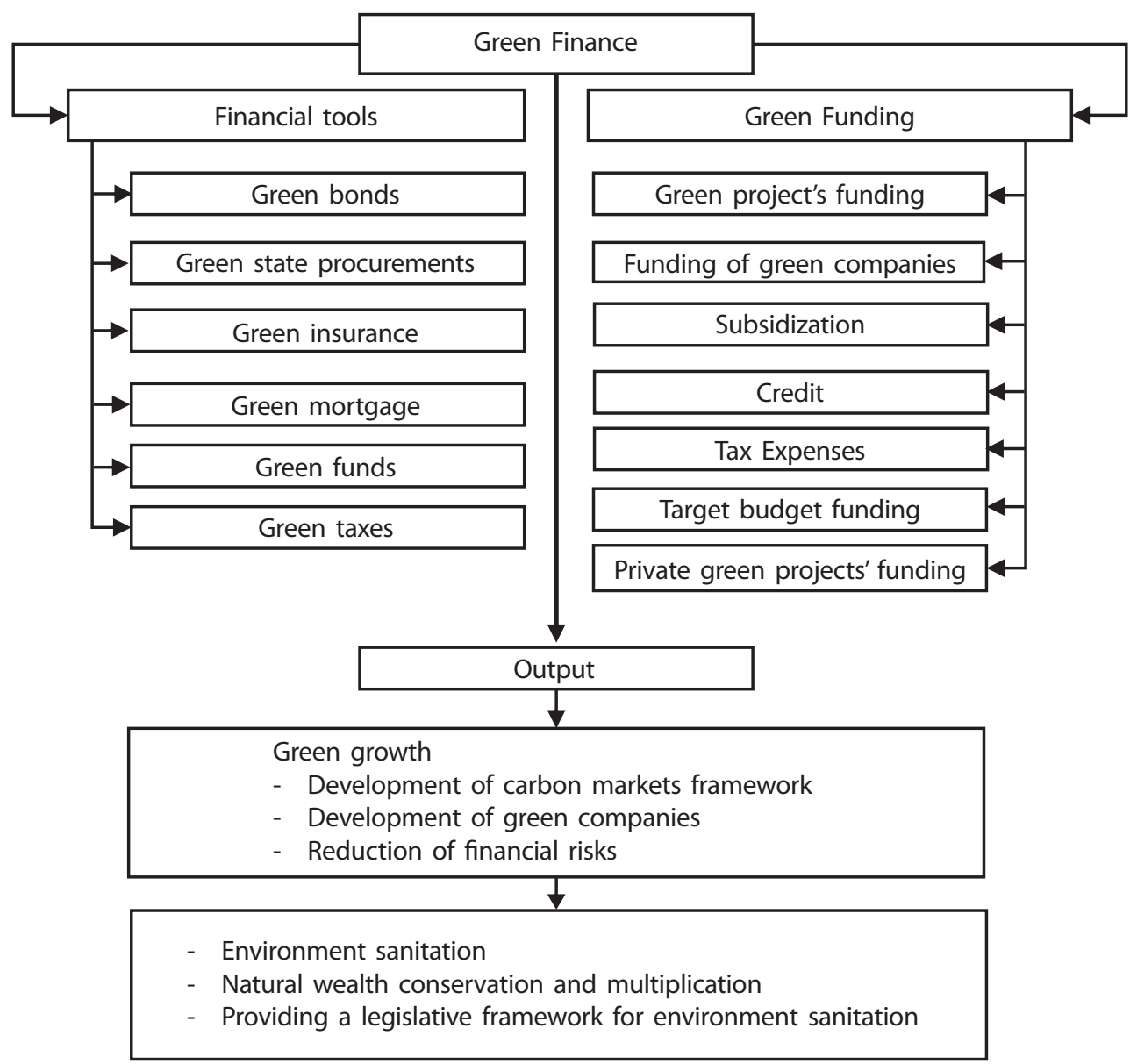

Source: Andreeva et. al (2018)

Andreeva et al (2018) highlight green projects both from revenue and cost streams (see Figure 3). However they do not show standard on reporting the activities. Barker (2019) elaborates RSPB's approach to natural capital accounting comprises in five steps; set up a straighforward approach, compose asset register, allocate maintenance and remediation cost, establish physical ecosystem, and manage service flows. After that, the institutions need to prepare a natural capital balance sheet such in Table 3 . 
Table 3. Nature Capital Balance Sheet

\begin{tabular}{lccc}
\hline \multicolumn{1}{c}{$\mathbf{2 0 1 6 / 7}$ (PV $\mathbf{~ m )}$} & Private value & External value & Total value \\
\hline Assets & $(73)$ & 681 & 608 \\
Baseline value (00/01) & - & 170 & 170 \\
Cumulative gains/losses & 21 & 26 & 47 \\
Additions/disposals & 93 & 155 & 248 \\
Revaluations and adjustments & 41 & 1,031 & 1,072 \\
Gross asset value & & & $(528)$ \\
Liabilities & - & & $(528)$ \\
Legal maintenance obligations & $(448)$ & $(80)$ & 544 \\
Other maintenance provisions & $(448)$ & $(80)$ & 951 \\
Total net maintenance provisions & $(407)$ & & \\
Total net Natural Capital Assets & & & \\
\hline
\end{tabular}

Source: Barker (2019)

Barker (2019) goes further by displaying accounting and reporting standards where IFRS is adopted. The accounting and reporting standards show in Table 4.

Table 4. Accounting and Reporting Standards

\begin{tabular}{|c|c|c|c|c|}
\hline & & \multicolumn{3}{|c|}{ Reporting domain } \\
\hline & & \multicolumn{2}{|c|}{ Annual report } & \multirow{2}{*}{$\begin{array}{l}\text { Supplementary } \\
\text { report }\end{array}$} \\
\hline & & $\begin{array}{c}\text { Financial accounts } \\
\text { ('back half') }\end{array}$ & $\begin{array}{l}\text { Management } \\
\text { commentary } \\
\text { ('front half') }\end{array}$ & \\
\hline \multirow[t]{4}{*}{$\begin{array}{l}\text { Primary } \\
\text { audience }\end{array}$} & Shareholder & $\begin{array}{l}\text { IFRS (listed companies) } \\
\text { FRS } 102 \text { (private } \\
\text { companies) }\end{array}$ & $\begin{array}{c}\text { Companies Act } \\
2006<<\mathrm{RR}> \\
\text { SASB } \\
\text { TCFD }\end{array}$ & CDP \\
\hline & Stakeholder & & & GRI \\
\hline & Management & & & A4S \\
\hline & & & & $\begin{array}{c}\text { Natural Capital } \\
\text { Coalition }\end{array}$ \\
\hline
\end{tabular}

Source: Barker (2019)

In a similar perspetive, Fleischman \& Schuele (2006) assert that since the late 1980s, more regulating bodies in many countries have issued new rules of disclosing environmental reporting in the annual report. They should present and disclose separate reporting on items such as expenditures for pollution prevention, clean up, and fines; actual and contingent liabilities for environmental clean, as presented in Table 5. 
Table 5. Environmental Reporting

\begin{tabular}{lcc}
\hline \multicolumn{1}{c}{ Type of report } & GFT 250 & Top 100* \\
\hline HSE reports & $73 \%$ & $65 \%$ \\
Sustainability reports & 14 & 12 \\
Environmental and social reports & 10 & 11 \\
Social reports & 3 & 12 \\
\hline
\end{tabular}

Source. KPMG (2002), *Top 100 companies from 19 countries, Source: Fleischman and Schuele (2006)

Minimol \& Makesh (2010) report green reporting among the Indian companies and they explain the scope of reporting in Figure 4. Further, Minimol \& Makesh argue that the scopes of green accounting are: First, environmental Cost Estimation. Expenses like production cost, research and development expenditures are taken into account in effort of protecting the environment. It can be classified into six environment related capital outflow. Second, the capitalization of expenditure. Company should capitalize the expenditure if its extends the life cycle of the environment, create efficiency, improve the safety of assets that possessed by the company at the time of acquisition, decrease the risk of environmental pollution and also the costs are bared in relation to the sale of asset of a business entity. Third, identification of environmental liability. Company should have contingency fund to do deforestation or other procedure to bring back the function of the natural condition that has been explored optimally. It is needed to compensate the third party who suffers loss from the company activity. Fourth, measurement of environmental liability. The measurement of environmental cost might be computable or even incomputable. If it is calculate-able, company can put the estimated cost in their financial position. Yet, if it cannot be calculated, provide a foot note to explain it at the notes of financial statement.

Figure 4. Scope of Green Reporting

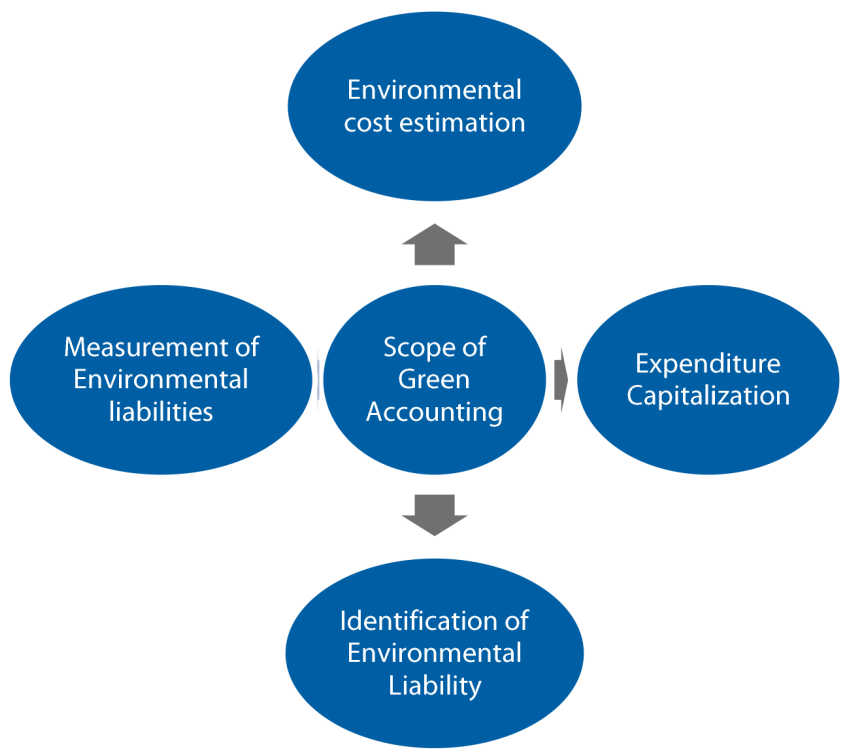

Source: Minimol \& Makesh (2010) 
Based on that scope of green accounting reporting, Minimol \& Makesh (2010) find that most of Indian Companies have the initiatives to promote the green accounting. However, they do not have any reserve or cost capitalizing regarding the environmental issue. Additionally, they do not have any expenditure on environmental asset (effort to raise the property value) as well as the environmental liabilities to pay their future obligations.

From the above benchmarks, we can now draw a statement for Zero Waste Accounting for IFIs to complement PSAK Sharia that has been set by The Indonesian Institute of Accountants (Ikatan Akuntan Indonesia, IAI). Currently, the following types of reports are obligatory to be issued by all IFIs in Indonesia: (a) Financial Position at the end of the period; (b) Comprehensive Profit and Loss during the period; (c) Statement of Changes in Equity during the period; (d) Statement of Cash Flow during the period; (e) Statement of Source and Uses of Zakat Fund during the period; (f) Statement of Sources and Uses of Qard Fund during the period; (g) Notes to the financial statements, consist of summary of important accounting policies and other policy explanation; (h) Comparative financial position statement in the beginning of the period when a Shariah entity implements a kind of accounting policy in retrospective or prepares a repeating disclosure on financial report, or when the Shariah entity reclassifies posts in its financial reporting

PSAK 101 draws a format on Statement of Source and Uses of Zakat Fund and Statement of Sources and Uses of Qard Fund that shows in Figure 5 and Figure 6.

Figure 5. Statement of Sources and Uses of Zakat Fund

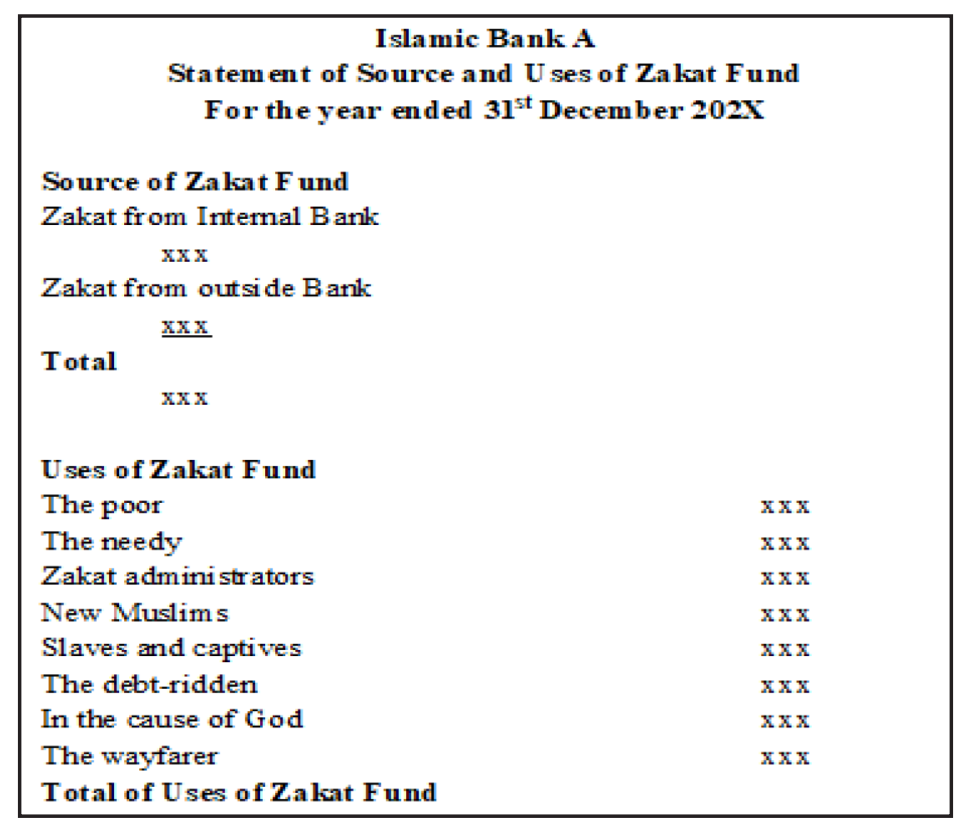

Source : IAI (2017)

The Zakat and Qard Fund reporting show the uniqeness of the IFIs. If we look deeper into Qard Fund Format, it has a non-halal income. Although in PSAK 101 states that it is income form late payment penalty, Islamic bank also should classify if the income comes from any project that harm the ecosytem and the community. Besides the standards 
of social finance, IFIs should also refer to the 1993 United Nation Protocol on National Environmental Accounting. This is described as the 'System of Integrated Environmental and Economic Accounting'. This protocol also addresses the business entities including IFIs in this case have a policy which is called "satellite account" which basically focus on the interaction of economic activity to the social and environmental issues.

Figure 6. Statement of Sources and Uses of Qard Fund

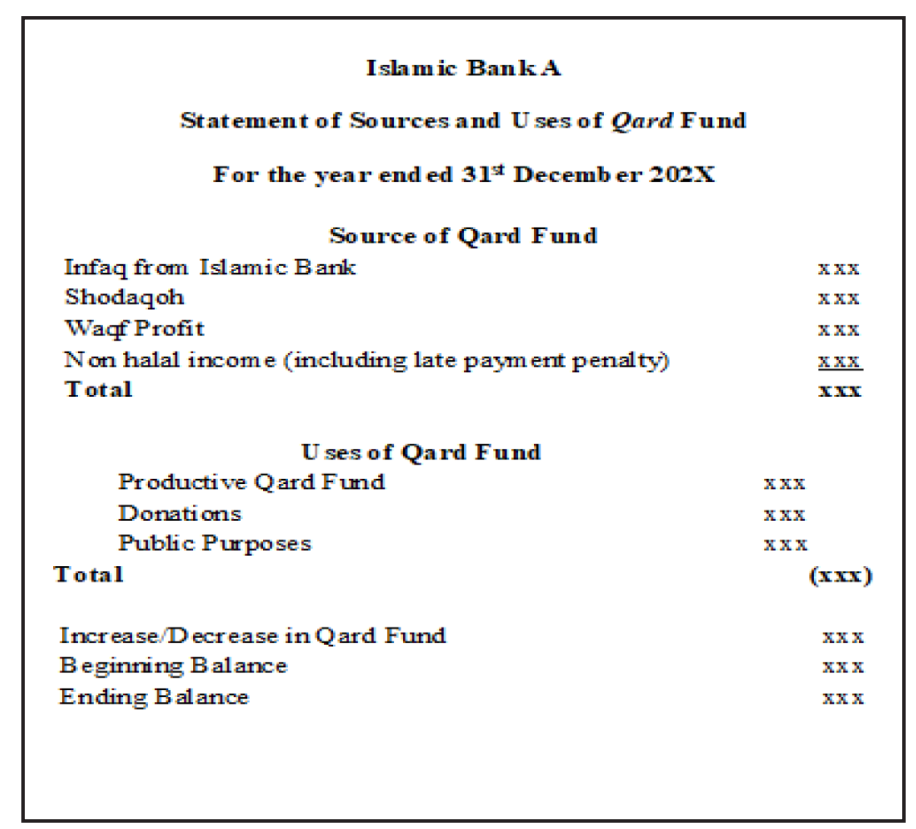

Source: IAI (2017)

The distinct characteristic of this account is poking all income as well as expenses which has conjunction to the third "P" of triple bottom line "Planet". Bell and Lehman (1999) draw an example of the satellite account as follow: (a) Account for Environment Protection which encompass the effort of preventing the effect of business especially the operational aspects to natural resources including the capital expenditure to prevent such harm that might be resulted from manufacturing process; (b) Use and Management of Natural Resource Account related to the activity that related to natural resource management such as timber, forest, water, and subsoil asset; (c) Repercussion of Natural Damage, which related to the cost that occurred to refurbish damage that has been happened especially after the exploration of a land; (d) Related Eco Activities which defines as the capital expenditures on the research and development toward better product with eco-friendly technology which can sustain the company longer; (e) Environmental Balance Sheet is a subset of account related the expenses, the revenues the depreciations of eco-assets as well as the liabilities that arise subsequently after the environmental explorations.

The above principles somehow might not be experienced by IFIs since they are a mere of intermediation entities that connect the surplus unit and the deficit unit. However, considering that IFIs have the feature of financing intermediation that allows them acting as investor or the owner of specific asset, IFIs need to think of Zero Waste Accounting for 
this purpose. There are Islamic contracts that position IFIs acting as investors in the equity participations contract like Murabahah (sale and buy), Mudharabah, and Musyarakah (equity financing), Ijarah (leasing). Such equity participations for instance, certainly require Zero Waste Accounting that report the activities of the following: a. Investment in plantation business; b. Investment in oil gas business; c. Investment in coal mining business; $d$. Investment heavy industry; e. Investment in Recycling Machines Investment; $f$. Investment in Bio-gradable Machine.

Other Islamic contract that may motivate IFIs to do Zero Waste Accounting is Ijarah contract. The Ijarah contract requires IFIs as the owner of the asset to manage its resources and lease it to the lessee. The Zero Waste Accounting is a must when IFIs possess assets such as: a. Coal Mine; b. Machinery with high pollutions, c. Green project related asset; d. River Filter Machine. As far as zero waste is concerned, all types of contracts above are relevant to be reported in the following format that shows in Table 6 .

Table 6. Future Zero Waste Financial Position Proposal

\begin{tabular}{|c|c|c|}
\hline Cost for Zero Waste Management & Type of Contract & Amount \\
\hline \multicolumn{3}{|l|}{ SDG No. 6} \\
\hline \multicolumn{3}{|l|}{ Clean Water and Sanitation } \\
\hline 1. River Filter Machine & ljarah & $x x x$ \\
\hline 2. Zakat fund to clean river & Social & $x x x$ \\
\hline \multicolumn{3}{|l|}{ SDG No. 12} \\
\hline \multicolumn{3}{|l|}{ Responsible Consumption and Production } \\
\hline 1. 1. Production of Recycling Machines & Mudharabah & $x x x$ \\
\hline 2. 2. Production of Bio-gradable Machine & Musyarakah & $x x x$ \\
\hline \multicolumn{3}{|l|}{ SDG No. 14} \\
\hline \multicolumn{3}{|l|}{ Life Below Water } \\
\hline 1. Sea cleaning project & Qard Fund & $x x x$ \\
\hline 2. Production of Bio-gradable & Mudharabah & $x x x$ \\
\hline \multicolumn{3}{|l|}{ SDG No. 15} \\
\hline \multicolumn{3}{|l|}{ Life on Land } \\
\hline 1. Segregation of Waste Machine & Istisna & $x x x$ \\
\hline 2. Separation Machine & Murabahah & $x x x$ \\
\hline
\end{tabular}

Source: Authors

\section{Conclusion}

The main purpose of this paper is to propose a model of zero waste accounting in Islamic Financial Institutions in Indonesia and how it is relevant to the achievement of SDGs. As this paper adopts interpretative approach which is essential to validate the research with "convincingness" method, the result is presented in the form of a disclosure model. The model is motivated with Maqāsid al-Shariah spirit that covers the need of the enterprises to disclose their activities that are related to zero waste. The limitation of this paper is on the methodology that only relies on the secondary data. As a recommendation for future research, it is commendable if this research is further enhanced through interview to test if the disclosure format is appropriate. The interview should be conducted with accounting standard setters, scholars who are expert in Islamic finance and authorities in charge on regulating IFIs in 
Indonesia. Should this research cover international coverage, the interviewees would be from international representations.

\section{References}

Abdurrachman, A. (2008). Prosedur Penetapan Keputusan Fatwa Dewan Syariah Nasional (Procedure for Determining Decision of the National Sharia Council Fatwa). AlMawarid, XVIII, 31-40.

Abdullah, S. \& Furqani, H. (2012). The Objectives of Shariah (Maqasid Shariah) in Takaful: Highlighting The Noble Practice. International Conference on Management, Economics and Finance 2012. Kuala Lumpur.

Agustia, D., Tjiptohadi S and Wiwiek D. (2018). The Mediating Effect of Environmental Management Accounting on Green Innovation - Firm Value Relationship. International Journal of Energy Economics and Policy, 9(2), 299-306.

Alsharari, N. M., \& Al-Shboul, M., (2019). Evaluating Qualitative Research in Management Accounting Using the Criteria of "Convincingness". Pacific Accounting Review, 31(1), 43-62.

Andreeva, O. V., Vovchenko, N. G., Ivanova, O. B., \& Kostoglodova, E. D. (2018). Green Finance: Trends and Financial Regulation Prospects. In: Grima, S. and Thalassinos, E. (eds). Contemporary Issues in Business and Financial Management in Eastern Europe, Contemporary Studies in Economic and Financial Analysis, 100 (1), Emerald Publishing Limited, 9-17. https://doi.org/10.1108/S1569-375920180000100003.

Ascarya. (2017). Integrasi Keuangan Komersial dan Sosial Islam (Integration of Islamic Commercial and Social Finance). Presented in Festival Ekonomi Syariah Regional Sumatera.

Barker, R. (2019). Corporate Natural Capital Accounting. Oxford Review of Economic Policy, 35(1), 68-87. https://doi.org/10.1093/oxrep/gry031.

Berg, A., Antikainen, R., Hartikainen, E., Kauppi, S., Kautto, P., Lazarevic, D., Piesik, S., \& Saikku, L. (2018). Circular Economy for Sustainable Development. Reportt of the Finisih Environment Institute 26.

Biswas, N. (2011). Sustainable Green Banking Approach: The Need of the Hour. Business Spectrum, 1(1), 32-38.

Chapra, U. (2008). The Islamic Vision of Development in the Light of Maqasid Al-Shariah. London: IIIT.

Fleischman, R. K., \& Schuele, K., (2006). Green accounting: A Primer. Journal of Accounting Education, 24(1), 35-66.

Gallhofer, S., \& Haslam, J. (1997). The Direction of Green Accounting Policy: Critical Reflections. Accounting, Auditing \& Accountability Journal, 10(2), 148-174. https:// doi.org/10.1108/09513579710166703.

Haniffa, R. \& Hudaib, M. (2007). Exploring the Ethical Identity of Islamic Banks via Communication in Annual Reports. Journal of Business Ethics, 76(1), 97-116. https:// doi.org/10.1007/s10551-006-9272-5. 
Hossain, D. M., Al Bir, A. T. S., Tarique, K. M., \& Momen, A. (2016). Disclosure of Green Banking Issues in the Annual Reports: A Study on Bangladeshi Banks. Middle East Journal of Business, 11(1), 1-12.

Islam, S. M., \& Das, P. C. (2013). Green Banking Practices in Bangladesh. IOSR Journal of Business and Management (IOSR-JBM), 8(3), 39-44.

Klapper, L., El-Zoghbi, M., \& Hess, J. (2016). Achieving the Sustainable Development Goals The Role of Financial Inclusion. Working paper of United Nations Secretary-General's Special Advocate for Inclusive Finance for Development.

Lahti, T., Wincent, J., \& Parida, V., (2018). A Definition and Theoretical Review of The Circular Economy, Value Creation, and Sustainable Business Models: Where are We Now and Where Should Research Move in the Future?. Sustainability, 10(8), 2799.

Minimol, M. C., \& Makesh, K. G. (2014). Green Accounting and Reporting Practices among Indian Corporates. Asia Pacific Journal of Research, 1, 51-60.

Muller, D. B. (2018). Circular Economy and The Sustainable Economy Goals. NTNU Industrial Ecology. Presented in Circular Economy Conference Trondheim 2018.

Mukhlisin M., Tamanni, L. Azid, T., Mustafida, R. (2020), Contribution of Islamic Microfinance Studies in Achieving SDGs, In: Elzahi Saaid Ali A., Ali K., \& Khaleequzzaman, M (eds.). Enchancing Financial Inclusion Through Islamic Finance, Volume 1. Palgrave Studies in Islamic Banking, Finance, and Economics. London: Palgrave Macmillan.

Ng, A. W. (2018). From Sustainability Accounting to a Green Financing System: Institutional Legitimacy and Market Heterogeneity in a global financial centre. Journal of Cleaner, $195,585-592$.

Owen, D., Gray, R., \& Bebbington, J. (1997). Green Accounting: Cosmetic Irrelevance or Radical Agenda for Change?. Asia-Pacific Journal of Accounting, 4(2), 175-198. https:// doi.org/10.1080/10293574.1997.10510519.

Schroeder, P., Kartika. A., \& Weber, U., (2018). The Relevance of Circular Economy Practices to the Sustainable Development Goals. Journal of Industrial Ecology, 23(1), 77-95. https://doi.org/10.1111/jiec.12732.

Subhan, M. (2015). Pemikiran Ekonomi Yahya Bin Umar Dalam Perspektif Ekonomi Modern (Yahya Bin Umar's Economic Thinking in a Modern Economic Perspective). Ulumuna, 1(1), 84-97.

Yunus, M. (2007) Creating a World without Poverty: Social Business and the Future of Capitalism. New York: Public Affairs. 